EXEMPLARIa Classica

Journal of Classical Philology

23, 2019, $\mathrm{xx}-\mathrm{xx}$

ISSN 1699-3225

\title{
A NEW COMMENTARY ON VIRGIL, AENEID BOOK 8*
}

\author{
RICHARD TARRANT \\ Harvard University \\ tarrant@fas.harvard.edu
}

Like the proverbial London buses, commentaries on Aeneid Book 8 seem to arrive in clusters separated by long intervals. The 1970s saw the nearly simultaneous appearance of commentaries by P. T. Eden (Brill, 1975), K. W. Gransden (Cambridge, 1976), and the posthumously published commentary of C. J. Fordyce (Oxford, 1977). The years 2017 and 2018 have likewise witnessed the publication of a trio of commentaries, by Keith Maclennan (London, 2017), James O'Hara (Indianapolis, 2018), and Lee Fratantuono and $\mathrm{R}$. Alden Smith, the volume under review. Maclennan's edition is specifically designed for use in schools and is therefore not comparable to the others, but in assessing the work of Fratantuono and Smith I have found it useful to set it against those four predecessors. ${ }^{1}$

This volume represents a second Virgilian collaboration between these scholars; only three years previously they published a commentary along similar lines on Book 5. The layout of that volume, the scale of the commentary, and even the place of publication inevitably prompted comparison with the commentaries on Books 2, 3, 7, and 11 by the late Nicholas Horsfall, a comparison that the authors incautiously encouraged by citing him as their primary inspiration among Virgilian commentators (p. viii). Horsfall responded with a furious denunciation in Scripta Classica Israelica 35 (2016), 143-6. Some of the features singled out for condemnation by Horsfall reappear in the present work, and other aspects of it also call for criticism, but I will aim to offer any negative comments in a dispassionate spirit.

As in their earlier work, "Smith once again bears the lion's share of the responsibility for the critical text and translation, and for the first draft of the introduction; Fratantuono for the commentary" (p. vii). For simplicity's sake I shall refer to the author of the introduction and text and translation as Smith (hereafter S.), and to the author of the commentary as Fratantuono

1* Lee M. Fratantuono - R. Alden Smith, Virgil, Aeneid 8; Text, Translation, and Commentary. Mnemosyne, Supplements, 416. Leiden: Brill, 2018, 802 pp., ISBN: 978-90-0436735-7.

O'Hara's commentary bears the same publication date as Fratantuono and Smith's, but it was available to and consulted by them in advance of publication (p. viii). 
(hereafter F.), apologizing in advance if in so doing I impute credit or blame where it is not due.

The relatively short introduction offers an overview of the book and a quick survey of previous scholarship. S. sees the epic as articulated in three sections of four books apiece, with Books 5 and 8 framing the middle section. (S. speaks of "those who prefer to view the Aeneid as a three-act tragedy rather than as a biform renewal of Homer's Iliad and Odyssey" (p. 2), but there is no need to choose between those structuring principles.) S. highlights patterns of three throughout the book, arguing that they prepare for and culminate in the concluding description of Octavian's triple triumph of 29 BCE. On the overall character of the book, S. (and in this he and F. are clearly as one) writes that "Aeneid 8 can be considered the most 'Augustan,' perhaps even the most 'positive' or 'optimistic' book of the epic-yet certain brighter features of its landscape will be seen to darken in light of the poet's backward glances, and especially in view of the progress of the Latin war and its divine resolution in Book 12" (p. 7). Elsewhere as well the mood of this book is defined with reference to what follows, especially the final scene of the poem, to which S. returns several times. One of those passages contains the extraordinary statement that "the poet's trick will be the revelation that the 'evil' side is actually victorious, at least insofar as Italy will dominate Troy" (p. 17). A passing reference cannot be expected to do justice to the complexities of the poem's ending, but the notion that in Virgil's eyes Italy and evil could be equated seems to me unlikely in the extreme.

In general $\mathrm{F}$. and $\mathrm{S}$. treat their predecessors with respect, but $\mathrm{S}$. does a disservice to Fordyce's commentary on Books 7 and 8 when he endorses the statement of John Henderson that "VIII is half missing, and dwindles." While Fordyce's notes on Book 8 are less full than on Book 7, no part of the book goes without comment, and the concluding description of Aeneas' shield receives detailed treatment. ${ }^{3}$

The introduction ends with "a Note on Manuscripts" (pp. 25-32) that marks the most significant difference between this volume and its predecessor. In the earlier volume, although we are told that S. "traveled extensively in Europe and a bit stateside to study in person both manuscripts and papyri" (p. viii), the apparatus consistently cited only two medieval witnesses, Paris BnF lat. 7906 (siglum p) and Wolfenbüttel Gudianus lat. $2^{\circ} 70$ (siglum $\gamma$ ). In

${ }^{2}$ Oxford Reds: Classic Commentaries on Latin Classics, 2006, 159.

${ }^{3} \mathrm{~S}$. is mistaken in stating that Oxford University Press "accorded separate volumes of commentary to each of the books of the Odyssean Aeneid, with but one volume for Books 7-8" (p. 4 n. 14). Fordyce's commentary is the remnant of a projected two-volume commentary on the entire Aeneid, Books 1-6 to be covered by R. G. Austin and 7-12 by Fordyce. Austin and Fordyce died within weeks of each other in 1974; the commentary on Books 7 and 8, the only part left in a nearly final form, was prepared for publication by J. D. Christie, who sets out the background in his preface (p. vii). 
constituting the text and apparatus of Book $8 \mathrm{~S}$. has aimed much higher, but as we shall see, performance does not match raised ambitions.

Unease begins to be felt with the opening sentence of the "Note": "the eighth book of Virgil's Aeneid, or at least much of it, is preserved in five ancient manuscripts of roughly the fourth to fifth centuries" (p. 25). While we are indeed fortunate that three ancient manuscripts, $\mathrm{M}, \mathrm{P}$, and $\mathrm{R}$, transmit the entire book, it would be quite a stretch to say that the other two contain "much" of it: F preserves only 27 lines and V has 52. The dating of the ancient manuscripts to "roughly the fourth to fifth centuries" is contradicted by S.'s own dating of $\mathrm{R}$ to the early sixth century (p. 30). Reading on, a classicist familiar with the guidelines of usus scribendi and difficilior lectio potior (which S. garbles as lectio difficilior vel potior) will be surprised to find them described as "the standard Metzgerian approach" (p. 25). ${ }^{4}$ After genuflecting to Sabbadini, Mynors, Geymonat, and Conte, S. summarizes his own contribution as follows: "all major and minor manuscripts that preserve Book 8 were studied in toto, some in digitized form, others in situ" (p. 26). There are over a thousand extant manuscripts of Virgil; S. has collated fewer than thirty. "Major and minor" refers to the ancient codices and the twenty-odd ninth-century manuscripts used by G. B. Conte in his Teubner edition of 2009. S. has added just one manuscript to Conte's collection, an 11th-century codex now in Vic (north of Barcelona). S. presumably included it following the lead of the Madrid edition by Luis Rivero Garcia et al. (see their introduction, pp. clxxxi-ii); it would appear to be an ordinary codex recentior. S.'s stated policy is to report all variants, even obvious scribal errors, that are more than merely orthographical (such as nichil for nihil or michi for mihi). This section ends with a list of manuscripts used and their sigla (pp. 30-2, oddly headed a "schema"). The entry for M (the codex Mediceus) contains no information on correctors or later hands, even though S. is aware of the complexity of the evidence (p. 27), and in the apparatus employs superscript numbers 1 through 6 to designate the various hands. ${ }^{5}$ The list omits one manuscript used by S., Paris BnF lat. 7928 (s) and wrongly states that another, Paris BnF lat. 13044 (u), lacks 7.748 to the end (which would mean that it has none of Book 8); S. has apparently misunderstood Conte's Latin description of the manuscript, which states that 7.748 to the end "supersunt."

${ }^{4}$ On the principle of usus scribendi S. strangely cites a monograph dealing with word division at line-end in German texts from 1500 to 1800 . Since S. also cites his own translation (with Jeffrey Hunt) of Fabio Stok's I classici dal papiro a internet as a treatment of text-critical method, it should be noted that the English version is marred by numerous misunderstandings of the Italian original.

${ }^{5}$ S. says that he used the form " $\mathrm{M}^{\mathrm{x}}$ " for corrections that could not be more specifically assigned; I have not found an example of that form in his apparatus. 
The "Note" ends with a statement about Wolfenbüttel Gudianus lat. $2^{\circ}$ $70(\gamma)$ that would make Karl Lachmann spin in his grave like a top: "this is a ninth century apograph of $\mathbf{P}$, and as such certainly worthy of being acclaimed as the most valuable of the non-antique witnesses" (p. 32). To the degree that $\gamma$ derives from $P$, it has no independent value as a witness; for that reason, Mynors only cited it where it differs from P. In citing it consistently S. can appeal to the precedent of Geymonat and Conte, but his claim that it has value as an apograph constitutes either an especially poor choice of words or a failure to grasp one of the basic principles of textual criticism. ${ }^{6}$

S.'s text contains no surprises, which is itself not surprising, given the relative stability of the Virgilian transmission. Its most remarkable feature is the complete absence of paragraphing, even though S. speaks of "our adoption of textual divisions for paragraph" (p. 29).

The apparatus is quite another story. It is even more inclusive than S.'s description would suggest, since it includes a number of Carolingian variants that I would regard as purely orthographical, such as aequos for equos, uphens for ufens, pugne for pugnae, capud for caput, eros, aeros, and haeros for heros, ostibus for hostibus, and so on. S.'s practice of recording even obvious errors fills his apparatus with variants such as exemplo and extimplo for extemplo, doctores for ductores, cepetis for coeptis, quan for quam, pecodumque for pecudumque, lotoriis for litoreis, sotios for socios, classa for classe, and many others. Trivia of this kind would have no place in a critical apparatus even if the ninth-century manuscripts were the oldest extant witnesses; with several ancient codices available, there is even less reason to cite them.

S.'s excessive punctiliousness in recording manuscript variants is counterbalanced by a relative disregard for the indirect tradition. The transmission of Virgil is unique in the extent to which readings are attested by ancient sources other than manuscripts: most prominently by the commentaries of Servius (and the expanded version of it generally known as Servius Auctus) and Tiberius Claudius Donatus, but also by a host of grammarians and rhetorical writers. Any reading found in one of these sources is on a par, chronologically speaking, with the readings of the ancient codices; for that reason, editors of Virgil customarily cite readings of the indirect tradition and provide lists of the relevant sources to complement their lists of manuscripts. S. does not include such a list, and the format of his apparatus often obscures the evidence of the indirect tradition. S.'s apparatus is drafted in negative form, meaning that only readings that differ from the reading in the text are cited. So, for example, when on line 411 we see exercet in the text and "exercens $\mathbf{M}$ " in the apparatus, we may infer that the other

${ }^{6}$ Conte at least tried to justify what would seem to be a departure from standard practice; see his preface, p. XIX n. 38. 
two extant ancient sources, $\mathrm{P}$ and $\mathrm{R}$, along with the Carolingian manuscripts, read exercet. Negative format raises no difficulties when it comes to manuscript readings, but Servius (to take him as an example) is not like a manuscript: there is not a Servian reading for every word in the text, and so it is often impossible to infer Servius' reading from a negative apparatus entry. Thus at line 477, where adfers is in the text and the apparatus reads "affres co affers $\mathbf{d}$ affert $\mathbf{n}$ adfer $\mathbf{w}$," a reader has no way of knowing that adfer was acknowledged by Servius. By contrast, Conte's apparatus omits the insignificant variants and cites Servius: "adfer w: "legimus et adfer et adfers' Seru." By my count S.'s apparatus omits some 70 readings of the indirect tradition that are registered by Conte.

Comparison of S.'s and Conte's apparatus raises a yet more disturbing question. In the roughly 100 places where each cites a reading from the ninth-century manuscripts, the accounts differ about four-fifths of the time. Some of the discrepancies are quite striking: in 60 the reading iramque is attributed by Conte to abfgjknr, by S. to bfn; 78 tandem is cited by Conte from dgkwz, by S. from dk; 244 according to Conte, the reading reseret is found in beijkrxyz, according to S. in ber. (Although there are exceptions, in most cases Conte cites more witnesses, even though both are reporting essentially the same body of manuscripts.) To check the accuracy of both editions I consulted the Paris manuscripts grstuyz, accessible through the Bibliothèque nationale de France Gallica website, and the Vatican manuscripts $i$ and v, accessible through the Vatican Library's digital archive. In addition, Stephen Heyworth kindly checked a number of readings in $f$ (Oxford, Bodleian Library Auct. F.2.8).

These soundings showed that Conte's reports are on the whole significantly more reliable than S.'s; to put it another way, in many places S.'s apparatus does not record all the relevant witnesses. In several cases the results were quite lopsided: out of 19 discrepancies involving manuscript g (Paris BnF lat. 7925), Conte was correct in 17 places; out of 20 involving i (Vat. Reg. lat. 1669), Conte was right in 18; out of 14 involving z (Paris BnF lat. 7927), Conte was right in 12; and of seven involving $\mathrm{f}$ (Oxford Bodl. Auct. F.2.8), Conte was correct in all. Not all the comparisons were as clear-cut: Conte's account of $\mathrm{t}$ (Paris BnF lat. 13043), for example, is less complete than S.'s; but the overall picture is beyond dispute.

I must conclude that S.'s handling of the manuscript evidence is unsatisfactory. In the context of the entire volume that need not be a serious impediment, since readers of F.'s commentary can simply ignore S.'s text and apparatus and use that of Conte (now the best critical edition, of which an improved second edition appeared earlier in 2019). There is in fact some reason to believe that $\mathrm{F}$. himself took much of his information about manuscript readings and conjectures from sources other than $\mathrm{S}$. 
Places where F.'s commentary refers to a reading or conjecture not recorded by $\mathrm{S}$.:

51 M's appallante (ante correctionem)

223 oculi "alii" apud Servium, accepted by some editors, discussed at length by F., and cautiously approved of by S. himself in an earlier context, ${ }^{7}$ as F. notes. (It is not clear why F. refers to this as "perhaps a textual crux that should never have been," since the readings oculis, oculos, and oculi are all defensible. His statement that "the point of the description is that Cacus was disturbed or confused with respect to his eyes" begs the question.)

237 F. (following Eden) credits Bentley with the conjecture aversam, while S. (following Geymonat) reports it as aversum. Whichever is right, Bentley did not make the conjecture "in Rufin. 57.16" (Geymonat, echoed by S.), since that line of Rufinianus is a citation of line 236.

On 275-7 F. explicitly refers us to Conte's apparatus for details about the status of the lines in $\mathrm{M}$ (on which S. is sketchy). F. misrepresents part of Conte's note: the hand that added the lines back in after they had been erased was not similar to the hand of Apronianus, but similar to the original hand ("man. librario simillima").

327 tum for et in Lactantius (recorded by Geymonat)

338 Romani in Tiberius Claudius Donatus

341 nomine in $\gamma$

344 monte (recc., Schrader)

380 "there is exceedingly weak support for reading dolorem here" (this from Geymonat, who cites "recc.")

406 Almost all the information in F.'s note comes from Conte, and F. contradicts S.'s report of P: "originally had infusum (corrected to the nominative)"; S. says that P corrected reads infuses, which is both wrong (the digital image is quite clear) and highly unlikely (could it be a typo?).

$420 \mathrm{~F}$. knows that Pac read gemitu.

$421 \mathrm{~F}$. says (following Geymonat) that M reads stridentque; S. says tridentque.

474 arcens, Arruns (cited from Geymonat)

$487 \mathrm{~F}$. follows Conte against S., saying that fluenti is in the Montpellier MS (x), where S. attributes it to Bern 167 (e) and Hamburg scrin. $52(\mathrm{k})$. $555 \mathrm{~F}$. says correctly that litora is found in several Carolingian MSS (11 according to Conte's apparatus), but S. records no Carolingian dissenters from limina.

672 This may be the only place where F. quotes S.'s apparatus: he cites brtow for spumabat (S. actually has bortvw), whereas Conte attributes the reading to bjrtxy. I can confirm that Conte is right about $\mathrm{y}$ and that $\mathrm{S}$. is wrong about $\mathrm{v}$.

Virgil (Malden, MA, 2011), p. 161. 
In addition, F. several times cites Servius where his reading could not be inferred from S.'s apparatus (e.g., on 477, 519, 527, 543, 559, 672, 692).

I will be brief on the translation, since users of the volume will have access to many excellent alternatives. S.'s style is painfully literal, resulting in much unidiomatic English: e.g., 90 "therefore with favorable shouts do they hasten their undertaken route," 171 "I shall release you happy because of our military help," 370 "terrified in her heart hardly for no reason,"

414-15 "by no means otherwise or more sluggishly late than at that time does the ruler of fire rise from his soft beddings," 468 "at last enjoy a conversation so permitted," 495 "they demand the king for punishment with prompt war."

There are also occasional slips. In line 8 cultoribus is taken as a dative of reference ("lay waste the farmers' broad fields"); F. correctly calls it an ablative of separation ("empty the broad lands of their husbandmen" Fordyce). 74 lacus "English 'lake' is often misleading," says F., but S. uses it nonetheless. 87-9 the syntax of sterneret aequor aquis is misrepresented ("the surface of the water spread out with its flood"). 97 medium ... orbem oddly rendered as "the middle arch." 407 "driven-off night" for "departing night," noctis abactae). 451 "the cave groans from the anvils set upon it" gives the wrong picture. O'Hara rightly glosses impositis as "set in position' on the cave's floor." 552 "chosen by lot" is the opposite of what exsortem means. 679 "together with the fathers and people, and the great gods, the Penates." It seems more likely that the di magni are not identical with the Penates. 684 "bedecked with the ships' beaks consisting of the naval crown"; rather "bedecked with the naval crown consisting of ships' beaks." 685 "with varied weapons" does not capture the image of a motley assortment. 707-8 "the queen herself ... appeared ... now and again to let the sheets loose"; iam iamque "expresses an action so imminent that it seems to have happened" (Fordyce, who renders "she was to be seen ... just in the act of letting the sheets run loose").

I turn to the commentary. Its scale-nearly a page per line of text-would lead one to expect a comprehensive treatment. In fact, F. displays limited interest or engagement in several important areas.

\section{ESTABLISHMENT OF THE TEXT}

F.'s references to manuscripts do not give the impression of close familiarity with the material. He regularly uses unidiomatic and uneconomical forms of reference such as "the Medicean," "the Palatine," and "the Wolfenbüttel." The ninth-century witnesses are often called "Carolingians," sometimes "Carolingian cursives" (a misnomer for minuscule). Particularly puzzling are several references to "Ribbeck's cursives." Otto Ribbeck used three ninthcentury manuscripts in his edition of Virgil; they appear in modern editions 
under the sigla a, b, and c. But references such as "the bulk of Ribbeck's cursives" (p. 316 on 194, p. 431 on 324, p. 443 on 338, p. 592 on 543), "several of Ribbeck's cursives" (p. 327 on 205), and "most of Ribbeck's cursives" (p. 369 on 257) make it appear likely that F. is applying the term to the ninthcentury manuscripts as a whole.

Some of F.'s textual notes are poorly phrased or imprecise.

On 90 "the variant celebrant ... has little textual support" ("manuscript support" is meant). "The sole attestation of furi in Parisinus lat. 7928" means that furi is attested only in that manuscript.

221 "Burman introduced the reading aetherii here" i.e., Burman adopted it.

$425 \mathrm{~F}$. credits Servius with the spelling Pyragmon, but Conte is surely right to infer from Servius' note (apo tou puros kai akmonos) that Servius saw the word as Pyracmon (the spelling with $\mathrm{g}$ in manuscripts of Servius is presumably a product of contamination from the manuscripts of Virgil). F. says that "Mynors prints Pyragmon here, in deference to the manuscript tradition and ancient commentaries (fortasse recte)." Here lies a great mystery. My original copy of Mynors, given to me by him in October 1969, has Pyracmon. The copy I bought when that one became too worn (a later printing, but not described as a new edition) has Pyragmon. I find it hard to believe that he would have altered a clearly correct form to an inferior one. In any event, Mynors offered no comment on his choice, so F.'s attribution of a reason for it is pure speculation.

$430 \mathrm{rutili} / \mathrm{rutuli}$, absurdly called by F. "a textual crux of some significance." If Mynors (and Conte) had not unfortunately preferred rutuli, we could easily have dismissed that form as due to a misplaced association with Rutulians (an association F. seems willing to entertain: "there may be no ancient evidence of a connection between 'Rutulian' and the color adjective, but a circumstantial case can be built").

$579 \mathrm{~F}$. (and S. in the apparatus) note that P's original reading nunc nunc was corrected to insert $o$, but do not say where it was inserted; Conte specifies that it was added before liceat, giving agreement with M's nunc nunc 0.

When confronted with a textual choice, F.'s preferred method is to begin by enumerating the decisions made by editors. The lists include non-scholarly editions such as those published by Reclam, Tusculum, and the Pléiade, which receive equal treatment alongside the critical texts of Geymonat, Mynors, and Conte. At that point F. often becomes tentative or aporetic. On 75 tenet vs. tenant: "The plural does seem to be the more usual Virgilian use, but a definitive rationale for a choice between the balance of the capital manuscripts is elusive." 108 tacitos/tacitis "in the end the manuscript reading [i.e., the reading of the capital MSS], for all its own problems, deserves the tip of the balance in its favor, even if the decision is made with caution and lack of confidence." On 194 tenebat/tegebat: "certainly tegebat is the difficilior lectio, but neither this nor pietas toward Geymonat [!] recommends the adoption." "We have printed tegebat, at any rate- 
though with reservations." 357 "with hesitation and lack of strong resolve, we have followed the bulk of the evidence." 420 gemitus / gemitum "The repeated strikes on the anvils may point to the plural. Note, however, that the singular accusative is more common in Virgil than the plural." 555 "In the end it may be that Tyrrhena ad litora was the original reading." 610 "We have printed egelido, but with deep reservations." 633 F. quotes Henry (with implicit approval): "I shall not pretend to decide dogmatically between the two readings."

The note on maesta vs. dicta in 583 represents the ne plus ultra of such waffling: "At the risk of indulging a Bentleyan penchant for recognizing the text's mood of pathos at this point (let alone of seeking to 'improve' the poet's work), we have preferred maesta, though with honest acknowledgement that a manuscript tradition is practically non-existent to support it. The original writer of the Medicean, however, would seem to be sympathetic."

\section{ThE GREEK BACKGROUND}

"Like all books of the Aeneid, Book 8 is imbued not only with the spirit of Homer, but also that of later Greek poets (especially Apollonius and Callimachus, and with no small influence from the world of tragedy." So S. in the Introduction (p. 6). It is therefore surprising that the Greek background has only a small role to play in F.'s commentary (a point made by Horsfall about the commentary on Book 5). Although G. N. Knauer is one of the two scholars to whom the volume is dedicated (the other being Karl Galinsky), his massive Die Aeneis und Homer is cited only twice, p. 278 on 152-175, p. 603 on 560. (It is possible that one or two other references have escaped my notice). The references are to the 1964 edition, even after Damian Nelis, reviewing the commentary on Book 5, noted its use instead of the 1979 second edition.

Citations of Greek appear to be limited to the notes on 114 (one line), 194 (a half-line), and 728 (one word cited in an etymology).

F. seems reluctant to quote directly, either in Greek or English translation, even when Virgil is closely engaging with a Greek predecessor, as in the simile of 22-5 based on Apoll. Rhod. 3.755-60. Although F. calls the simile "celebrated" and the imitation of Apollonius "famous," he gives only a paraphrase.

$31 \mathrm{ff}$. patterning of the scene after Odysseus' awakening on Ithaca (on which see Eden)

67 Eden (following Heyne) cites parallels in Homer and Apollonius.

71 only a bare line reference to Odyssey $13.329 \mathrm{ff}$. and to Theocritus 18.50 for the repetition of nymphaea

90 for the Apollonian intertexts we are referred to Nelis. The patterning of Aeneas' arrival and reception at Pallanteum on Telemachus' arrival on Pylos in Odyssey 3 is unremarked (except for a glancing reference to the rites being celebrated there). Eden has a full note detailing similarities and differences. 
131 "the expression and its sentiments are Homeric," but no passages are cited.

$175 \mathrm{ff}$. On the link to Iliad $7 \mathrm{~F}$. just refers to Clausen. No reference to Odysseus' reception by Eumaeus in Odyssey 14 (fully discussed by Eden).

183 Most other comms. note that perpetuus is the equivalent of Greek dienekes.

184 F. cites only one Iliad passage (no Greek or English); most comms. note that this is a Homeric formula, and O'Hara gives details (14 times in Odyssey, 7 in Iliad).

263 abiuratae no reference to Hom. Hymn Herm. 274 ff., cited by Eden as Virgil's "underlying source" for the idea that Cacus denied having stolen the cattle

353-4 The Homeric coloring of the lines is played down: Iliad 1.166 $\mathrm{ff}$. is referred to (but not quoted) in a paraphrase of Fordyce, and on nimbus ... cieret $\mathrm{F}$. says only that "Jupiter is depicted in conventional Homeric terms as if cloud-gathering Zeus" (no reference to the Greek). 364 "The topos of the reception of a great man at a humble threshold ... can be traced back to the Odyssey" (no details given).

370 "The goddess of sexuality will use wiles similar to those of Hera with Zeus at $I l .14 .159 \mathrm{ff}$., though comparison of Venus' emotional state here with Homer's Hera is instructive" (none is forthcoming).

383-4 "The present verse refers to the first book of the Iliad, just as the following refers to the Aethiopis" (no details, and the Aethiopis has not been previously mentioned).

387 " $<$ niveus $>$ also has a hint of usurpation of the common $(24 \mathrm{x})$ Homeric epithet for Hera" (which is not named).

393 "How different is all this from Homer Il. 18.368 ff." (no further comment).

$407 \mathrm{ff}$. F. seems to downplay the influence of the similes from Homer and Apollonius ("it is difficult to determine the full extent to which any of them were on the poet's mind"); he gives only line-numbers. Fordyce and Gransden cite the relevant lines in Greek.

$425 \mathrm{ff}$. F. cites Ap. Rhod. $1.721 \mathrm{ff}$. but does not quote any of the passage. 452-3 no reference to Callimchus Hymn 3.59-61, cited by Eden and O'Hara as the inspiration for Virgil's manipulation of meter to reflect sense

$454 \mathrm{ff}$. The Homeric background of the scene barely registers. 459 "The plural umeris follows Homer Il. 2.45" (not quoted); 461 "Evander has two dogs with him in the manner of Telemachus at Od.2.11." Eden has an extensive note (based on Knauer), and O'Hara has a shorter version. 516 grave Martis opus F. comments "the model is Homeric (Il.11.734)"; Fordyce and Gransden quote the Greek, O'Hara gives a translation.

$523 \mathrm{ff}$. On the portent O'Hara notes the Odyssean intertext (15.160-81). $560 \mathrm{ff}$. The link between Evander's speech of farewell to Pallas and that of Jason's parents in Ap. Rhod. $1.260 \mathrm{ff}$. is noted by O'Hara.

589-91 F. gives bare references to $I l .5 .4 \mathrm{ff}$. and Ap. Rhod. $3.956 \mathrm{ff}$., but does not mention $I l .22 .317 \mathrm{ff}$. (Achilles compared to the evening star), noted by Eden. 
670 For Cato in the Underworld, Gransden cites the Homeric model of Minos at $O d$. 11.569.

\section{SyNTAX, METRICS, AND LANGUAGE}

For a good deal of this material F. is content to refer to others, Eden and Gransden in particular.

F.'s treatment of syntax shows excessive deference to the De casuum syntaxi vergiliana (1882) of F. Antoine, many of whose categories now seem quaintly outmoded. F. takes mihi in 160 as a "dativus dynamicus vel energicus"; it would seem to be an ordinary dative of reference; similarly mihi in 163. (The index registers the usage in 160 but not 163.) Likewise with tuendo in 265, described as "ablativus instrumenti expletivus" (not in the index), i.e., an ablative of means. At 292 fatis Iunonis, F. again follows Antoine in labeling "genitive of source or origin" (also not in the index); surely a simple possessive? In 508 mihi (another dative of reference) is glossed, after Antoine, as "dativus acquisitionis"; similarly in 512, where the dative is regular with the verb indulgere in the sense "show favor to." (The index records the use in 508 but not 512.)

Points not made by $\mathrm{F}$. which are made by one or more of his predecessors: 1-3 accelerando created by progressively shorter $u t$-clauses (Eden)

10 metrical shape of the line (Gransden)

15 negative connotations of struere (Gransden, Eden)

15 his coeptis sequential rhyme (Eden)

22 position of $u b i$ in clause (Eden)

27 alituum for alitum possibly an Ennian innovation (Eden, Gransden)

28 nothing on the cum inversum construction (long and interesting note in Eden)

30 seram adjective for adverb (Eden)

32 populeas ... frondes adjective-noun framing (Eden)

32 anastrophe of inter (Eden)

49 litotes of haud incerta (Fordyce)

57 recto flumine as "straight up the river" rather than "up the straight river” (Eden, Fordyce, O'Hara). F.'s note ties itself in knots.

68-70 F. cites only one detail from Gransden's extended note on the style of these lines.

70 On the variant sustulit, Eden plausibly suggests a reminiscence of 9.17.

71 On the repetition of nymphae O'Hara refers to Wills (1996), p. 51.

78 numina F. gives a list of occurrences of tua numina; Gransden and Eden have useful things to say about the force of the word.

95 Fordyce is fuller and clearer on the nautical sense of superare.

118 Edem clarifies the sense of profugos egere ( $\mathrm{F}$. adopts the interpretation that Eden showed to be wrong). 
$127 \mathrm{ff}$. I can find nothing on the similarities between Aeneas' speech to Evander and that of Ilioneus to Latinus in Book 7 (a point noted by several other commentators).

$134 \mathrm{ff}$. nothing on the invocation of shared genealogy in actual diplomatic practice (discussed at length by Eden)

136 The difficulty caused by advehitur Teucros is noted by Eden.

137 nothing on Servius' assertion that Aeneas is mistakenly conflating three originally distinct Atlases (mentioned by O'Hara)

$157 \mathrm{ff}$. no reference (that I can find) to the parallel situation recalled in Iliad 3.204 ff., only a glancing allusion to one aspect of it (p. 286 on cunctis)

178 F.'s note on invitat does not deal with the verb's special sense when combined with an ablative ("entertain," almost = accipere), well discussed by Fordyce.

193 On vastus Eden is fuller and more enlightening.

194 Caci facies ditto (citations from Homer and the tragedians)

201 auxilium adventumque Eden details the Homeric background to hysteron proteron.

201 adventus used of the epiphany of a god (Fordyce)

201 maximus O'Hara notes the anticipation of the Ara Maxima.

201 ultor O'Hara notes the prominence of vengeance in Evander's account (and in his speeches generally).

202 tergeminus Gransden suggests a connection with Octavian's triple triumph.

202 Geryon O'Hara has a full note suggesting that some earlier accounts of Geryon's death portrayed him sympathetically.

205 Eden notes the epic/tragic coloring of personified mens.

216 Gransden discusses the structure of the tricolon, citing Henry on "theme and variations."

223 For turbatum oculis Fordyce aptly compares Aesch. Pers. 168.

223 Eden's note on ilicet traces the word's evolution.

224 Fordyce notes the novelty of the metaphor in alas.

229 Eden shows how the meanings of lustrare develop from the original purificatory sense.

230 fervidus surprising that $\mathrm{F}$. does not note the appearance of the adj. of Aeneas in the final scene (12.951) (noted by O'Hara)

231 Aventini. For the gen. F. refers to Horsfall on Aen. 6.659; Eden's note is more informative.

233 no comment on the meaning of praecisus (Fordyce and Gransden gloss the word)

248 insueta rudentem for the adv. acc. F. refers to Antoine rather than to Eden's excellent note.

260 in nodum Fordyce illustrates the "modal" use of in, and Eden and O'Hara note that nodus is a technical term of wrestling.

260 angit "See Eden for the use of the verb of mental anguish and emotional disturbance"; Eden notes that the verb had been restricted to mental states before Virgil, who extended its meaning. (O'Hara cites G. 3.497.)

261 Most other comms. note the proleptic use of elisos and siccum. 
265-6 For spectators gazing eagerly on the corpse of a defeated monster one might compare Ovid Met. 8.422-4 (the Calydonian Boar, another fire-breathing creature distinguished by bristles).

268 minores $\mathrm{F}$. does not consider the possibility (suggested by G. Williams and mentioned by O'Hara) that Virgil is blending the perspectives of Evander and that of his own time.

275 "For the question of Hercules' being invited to take part in the rite see Morgan" etc. This may be an oblique reference to the interpretation of communis as "sharing in the rite" and addressed to Hercules (an interpretation designed to get around the difficulties of taking communis as meaning "common to Trojans and Italians"), an issue discussed by Eden and noted by O'Hara.

278 F. refers to J. Wills 1987, but does not report the point of his discussion, that Virgil used scyphus only once because the word had appeared only once in both Homer and Theocritus. (Contrast O'Hara.) 283 no explicit comment on the sense of instaurare here ("to resume after an interruption"), discussed by Eden and Fordyce

$287 \mathrm{~F}$. does not consider the unlikelihood of old men taking part in Salian dances (see Eden, whose point F. misrepresents).

288-9 ut-clause after a verb of speaking (rare in prose, perhaps under Greek influence); see O'Hara.

289 monstra ... anguis hendiadys, as noted by Eden and Gransden 293 On Du-Stil in hymns F. refers only to Henry's comparison of the Te deum laudamus. Other comms. (Fordyce, Eden) cite the classic treatment, Norden's Agnostos Theos.

293 On the striking switch from third-person to second-person Gransden and Fordyce refer to Ap. Rhod. 2.700-19 (a hymn to Apollo). 293 Eden notes the Greek flavor of the multiple compound adjectives, comparing, e.g., Hom. Hymn Pan $1 \mathrm{f}$.

315 F. cites Od. 19.163 without noting that Penelope is alluding to something already "spoken of long ago" (palaiphatos); see Eden and Gransden.

353 nothing on the condensed cum saepe ("when, as often happens"), noted by all other comms.

354 nimbos ... cieret O'Hara comments on Virgil's avoidance of Greek compounds.

358 F. refers to Eden's helpful note, but it is Fordyce who cites the relevant Virgilian parallels.

377 no comment on the genitive (for which see Gransden and O'Hara) 382-3 Eden compares $I l$. 18.457-60.

382 O'Hara comments on idem used to highlight a change in a person's attitudes or actions.

393 dolis Gransden and O'Hara compare Iliad 14.329, where Hera is dolophroneousa.

394 aeterno Gransden is helpful ("life-long," not "eternal").

$407 \mathrm{ff}$. O'Hara remarks on the connection between the woman and Vulcan as craftspeople working under duress for hire (and cites Casali, $G \& R 2006$ for the possibility that the connection extends to Virgil). 
409 F. has a half-page of catch-all information on Minerva, but does not mention the use of the goddess's name as a metonymy for weaving (noted by all other comms.).

411 no comment on the sense of ad lumina (cf. Fordyce)

441 O'Hara cites other echoes of the opening words of the poem.

448 No comment on the seven-layered shield being fashioned for Aeneas. All other comms. compare the shield of Ajax in the Iliad and the shield of Turnus.

$485 \mathrm{ff}$. F. gives a reference to the passage of Cicero preserved in Augustine, but does not cite the text (as do Gransden, Eden, and O'Hara).

487 no comment on the syntax of tormenti genus (acc. in apposition to the entire sentence), as in all other comms.

498 Eden comments on the idiomatic use of the active infinitive in signa ferre iubent.

521 F.'s note on Anchisiades is less focused than those of other comms., who note Warde Fowler's argument that the patronymic signals a premonition of the death of Pallas; "Aeneas the son thinks of Pallas the son" (Eden).

$533 \mathrm{~F}$. does not note the emphatic force of ego: "It is I who am summoned (and not Pallas, as you, Evander, might think)."

543 Eden notes the boldness of hesternum ... larem ("the lar to whom sacrifice had been made the day before").

557 Fordyce's excellent note sets out the range of meanings for imago in Virgil.

$572 \mathrm{ff}$. O'Hara highlights the links between the end of Evander's speech and words of Dido; F. has a reference to Newman and Newman (2005), but does not give any prominence to the parallels.

593 no comment on the "curious paraphrase" (Eden) qua proxima meta viarum

$626 \mathrm{ff}$. F. has no general note on the description of the shield, as do all other comms.

630 O'Hara refers to Lessing's discussion of the difference between Homer's shield and Virgil's.

659 Fordyce and Eden are fuller on the possibility that vestis here = barba (Servius).

660 Eden has a fine note on the diminutive saguli and diminutives in general.

664 Eden mentions a denarius of $17 \mathrm{BCE}$ with the head of Augustus on the obverse and ancilia and apex on the reverse, suggesting that the combination may have been inspired by Virgil's line.

670 Gransden and Eden discuss the specific sense of dantem iura.

676 cernere erat F. writes "a Grecism as we begin a war in Greek waters," but does not explain (the Grecism consists in using est to mean "it is possible"); cf. Fordyce and especially Eden.

678 Eden is helpful on the contemporary connotations of agens Italos. 695 Fordyce and O'Hara cite evidence for taking Neptunia arva as an Ennian reminiscence.

703 O'Hara notes the connection between Discordia and civil war. 
708 F. cites instances of iam iamque; Fordyce describes its force.

726 F.spends much of a page on the Callimachean import of mentioning the Euphrates six lines from the end of the book (after Thomas and Scodel 1984), but does not cite the other Virgilian references that clinch the allusion (in Georgics 1.509 and 4.561). S. in the introduction (p. 24) makes the connection to recusatio.

If one asks what does engage F.'s interest, the list would be headed by parallels and their alleged associations. The commentary contains some 150 notes that consist of listing the occurrences elsewhere in Virgil of a word or combination of words, with no attempt to draw a conclusion from the data. More interesting is another large set of notes that combine enumeration of appearances with a statement of their significance. F.'s method is to read terms that appear in Book 8 against their other occurrences in the epic; to the degree that he judges those other instances to be either positive or negative, the "associations" of the word in question are said to be positive or negative. While in some cases F. concludes that a word's associations are "mixed" (e.g., 43 sus, 62 persolvere, 71 nymphae, 82 candidus and candere, 252 mirabile dictum) or "balanced" (e.g., 44 eniti, 146 Daunius, 157 memini) or "interesting" (e.g., 86 tumentem, 612 perfectus, 614 acer), much more often he diagnoses negative associations with adjectives like "dark" (e.g., 83 conspicere, 87 leniit, 91 labitur, 106 tepidus, 181 ministrare, 184 fames, 588 chlamys, 599 niger, 716 tota urbs), "ominous" (e.g., 66 se condidit, 79 memorare, 83 conspicere, 215 mugire/mugitus), "baleful” (e.g., 167 chlamys, 369 fuscis ... alis, 467-8 mediis aedibus), "troubling"(e.g., 45 albus, 90 rumor), "grim" (e.g., 83 viridis, 589 Lucifer), or "not particularly positive” vel sim. (e.g., 64 caeruleus, 124 amplexus, 284 cumulare, 341 nobilis, 350 dirus, 468 aedes, 480 praeclarus, 685 variis ... armis). The invocation of negative associations is the principal means by which $\mathrm{F}$. advances a pessimistic reading of the text that often stands in contrast to its apparent meaning.

F. himself may have grown somewhat weary of this exercise; the first third of the book (lines 1-250) accounts for more than half of the examples.

This game of associations is played with no clear rules. One could easily construct a set of notes that use appearances elsewhere to draw an opposite conclusion. For example, with the combination placidaeque paludis (88), an enumeration of uses of placidus would presumably yield predominantly positive results; these could then be invoked to negate the underworld associations of palus.

Or on 165 sub moenia, where F. says "the parallels are ominous," one refers to the Elysian Fields, the other to Latinus' city when under threat by Aeneas. One could equally well argue that the parallels are ambiguous or divided in their associations. 
Or on 278 (similar to 1.736), where F. sees "a baleful association to give the scene a dark closing"; one could with equal plausibility argue that the scene in Book 8 offers a corrective to the one in Book 1, setting proper ritual and a genuinely convivial scene against the doomed banquet in Dido's palace.

A more fundamental objection to F.'s method is that it treats individual words as independent carriers of associations, ignoring the fact that the words in a text only exist as parts of phrases and sentences, and that context has a large part (one might even argue a controlling part) in determining which of a word's potential associations is being activated at a given moment.

F. seems to regard it as axiomatic that repetition is always at least potentially significant. A propos his note on 28 aetheris axe (seen as "ominous" because of its other appearance, at 2.512), one would like to see him engage with Eden's crisp assertion that "as usual with such small repeated phrases there is no cross-reference between their contexts," or his tart dismissal of Putnam's Poetry of the Aeneid (which for F. has the status of Holy W rit) as "an imaginative fantasy based on the improbable assumption that he did" (i.e., use repeated phrases as Wagner used Leitmotivs).

For F. a word's associations include passages of the poem which are subsequent to the one in question. This is explicit in the note on 129 non equidem: "once looking back to the abandoned Dido, then, and once in anticipation of the memory of the doomed young hero Lausus."

There are some places where I found that F.'s enumerations had some interest: 6 efferus, 119 ferte (used at moments of high emotional intensity), 201 ultor ("overall not a happy set of occurrences"), 356 reliquiae, 388 cunctantem (although F.'s conclusion "several occurrences, then, but never outside moments of high emotional energy and dramatic suspense" is underwhelming), 730 mirari as a key word in the book. It is interesting to see how often the combination of fata and poscere occurs (cf. note on 477), although $\mathrm{F}$. does not make anything of it

Another area in which F. shows considerable interest consists of divining subtexts and allusions, many of which work in opposition to the surface meaning of the text. Most of his alleged examples strike me as unpersuasive.

18 Laomedontius as imputing treachery/trickery to Aeneas. That would be unsubtle of Virgil, and also unfair, since Aeneas is not at this point engaging in such tactics.

19 on cuncta videns "just possibly there is a hint of a borrowing of the idea that the sun ... sees all"

71 "The anaphora may serve in part to highlight the inappropriateness of Aeneas' prayer as his first invocation" (a point on which F. seems fixated).

83 on sus "if there is anything ridiculous about the ending, it serves only to undercut the solemnity of the vision." F. is perhaps unduly influenced by Horace's ridiculus mus (AP 139). 
85 "The calm and seemingly unworried Aeneas renders his offering to a divinity [sc. Juno] whose anger may well have increased in the course of the night and first hours of the new day." This is at best baseless speculation, at worst a misplaced approach to characters in an epic, wondering what they might be feeling when they are not present. Similarly on 301 "one imagines that Juno would be irritated by the high praise of Jupiter's bastard"; on 531 "the capricious Venus, for her part, may be imagined as having no sense whatsoever of the fate of Pallas" (several other notes, e.g., on 589 and 590, fault Venus for not caring about Pallas). 723 "the indignant remarks of Numanus Remulus about the Trojans ... with which Juno would be in complete sympathy."

137 "Any hints of Mercury's chthonic responsibilities look forward now to the loss of Pallas." The existence of those "chthonic responsibilities" is itself in doubt (there is no good reason to identify Mercury as the unnamed deus of 6.749), and one has to look hard to see a hint of them here.

162 "the repetition highlights the role of Laomedon in the Troy story, perhaps with a deliberate reminder of his notorious deceit and trickery." Why would Virgil wish to remind his readers of that in this context?

178 "Does the maple wood of the chair signal some deceptive quality in the present scene?"

181 "there may be a hint of the great labor of the goddess in quest for the abducted Proserpina" (surely not; the reference is to the labor of kneading etc. to produce bread, a sense that F. acknowledges as possible).

215 querelis the lowing of cattle is not likely to have elegiac associations. 231 "Is there a hint of the idea that Hercules' careful reconnaissance and investigation of the scene constitutes a purificatory rite?"

$235 \mathrm{~F}$. seems to assume that the dirae volucres allude to the Dirae.

236-7 laevum ... dexter "It is possible that Virgil meant the directional adjectives here ... to be more indicative of luck and omen than of mere 'left' and 'right."'

243 "Is there an allusion here to Hercules' engaging in combat on a day when it was forbidden to do battle except out of strict necessity?" 245 pallida "The semantic connection of the name Pallas is also perhaps in the poet's mind."

On pallidus: "poetic and not particularly common $(2 \mathrm{x}$ in Plautus and Catullus, 4x in Propertius)." Add 15x in Ovid, 7x in Sen. Trag., 7x in Lucan, 15x in Statius, $2 \mathrm{x}$ in Valerius Flaccus, $2 \mathrm{x}$ in Silius, $5 \mathrm{x}$ in Juvenal. 256 "We may ask here and throughout the episode the question of how well Hercules fits the model of what we might call the "ideal king." Why should that question arise, since nothing in Virgil's text implies that description of Hercules?

264 caelo ostenduntur "There may be a hint of the hero's calling the heavens to witness that Cacus is guilty of the crime for which he has been slain." 
276 "Scansion aside, are we to think of the notion of the union of peoples here via a play on words?" (i.e., populus and populus)

287 "Did anyone think of Caesar's March elimination in light of this lore?"

296 "Is there any connection to the use of ianitor here with Janus, who was mentioned in the Carmen Saliare?"

310 facilis oculos "we may think, too, of 6.126 facilis descensus Averno"

319 " $<$ Saturn's $>$ name contains that of the hero Turnus who opposes Aeneas."

330 "Thybris was a giant (are we to think of the hybristic Cacus?)." Again at 540 (Aeneas' invocation of Thybri pater) "Do we hear the word hybris in Aeneas' invocation?"

345 A reference to the Argus who was set by Juno to guard Io seems unlikely.

352 "It is possible that Evander's uncertainty serves in part, at any rate, to highlight the deposition of Saturn by his son" (the qualifiers are noteworthy).

379 "We may be reminded here of the king's grandson Priamus (the son of Polites), who was a turm leader in the lusus Troiae."

391 "Lightning was a traditional concomitant of the commencement of Octavian's building program.”

395 "Is there any hint here of Hephaestus' role as a restorer of divine harmony from $I l .1 .571 \mathrm{ff}$.?"

400 "Here ... we may wonder if <bellare> carries any reference to prettiness and feminine loveliness (i.e., bellus)?"

405 optatos "the embraces were exactly what the goddess wished." Eden is emphatic that optatos means "that he longed for," and this seems more likely.

425 "It is conceivable that any sexual action that the god had expected from his wife's seductive appeal has been transferred to the scene of the slavish labor on her behalf."

460 "One wonders if the panther was deliberately referenced here to signify the entire world of animals ... the aged Arcadian monarch as zoological/hunting master."

505 "One might wonder if there any thoughts of the suspicions of some that Caesar had had monarchical ambitions."

511 on pars patriae "The phrase is curiously reminiscent [!] of the later Augustan title pater patriae."

518 I do not understand F.'s note: "centum is a commonly cited number in poetry, and the presence of the two Arcadians [i.e., Evander and Pallas?] contributes to a sense of doubling."

$531 \mathrm{~F}$. overreads the significance of there being no explicit prior mention of a promise by Venus, concluding that Aeneas misinterprets the heavenly portent-an idea explicitly refuted by Venus' words at 612-13.

557 F. seems to take Martis imago literally, as announcing an appearance of Mars ("Mars has in no way been hampered in his advance 
by the change in work orders"); but Mars here is the metonymy for bellum.

564 "Was Virgil playing on the semantic associations of the first part of the goddess' name [i.e., Feronia] and the notion of wildness and savagery?"

575 On incolumis "columen may have been heard in the adjective."

593 "The dust cloud is a realistic detail that also introduces a note of meteorological gloom" (unlikely, given the juxtaposition of the bright fulgentis aere catervas).

610 egelidus "It is possible that Venus' epiphany warms the waters of the stream ... likeliest may be that the goddess of spring has raised its temperatures."

615 "the willingness of the goddess to allow her son a sign of physical affection" rather underplays the force of amplexus nati ... petivit.

625 textum "the weaving image may introduces [sic] a Minervan note to the description of the Schild"

631 "The memory of fratricide colors the lush image with a tinge of internecine strife and the painful memory of the Roman civil wars." Virgil/Vulcan has very carefully steered our attention away from recalling that Romulus would kill Remus.

658 "One might consider capitalizing noctis."

659 on caesaries "Is there any hint in all this of an image of Caesar as an invader of Rome in the context of his war with Pompey?"

675 aeratas classis "we may think, too, of the decline of man and the Bronze Age of heroes."

680 geminas ... flammas "other doublets may lurk; certainly Romulus and Remus."

681 "Can one think of Julius Caesar in an Actian connection without wondering what his emotions would have been with respect to his former lieutenant and quondam lover?"

686 victor ab Aurorae populis "Is the doomed Antony associated here with Aurora's son Memnon?"

697 geminos angues "twin snakes; twin children of the she-wolf"

710 The naming of the wind Iapyx prompts connections that include identifying the wind with the doctor of Book 12. "Is the reference to Iapygia in the Camilliad a reminder of the wind that ensured the success of Cleopatra's flight from Actium?" "In Book 12 Iapyx will not be able to save Aeneas from his grave wound-that which saved Cleopatra would not do to save Aeneas, after all."

719 caesi iuvenci "It is certainly within the realm of possibility that Virgil's contemporary audience might have remembered such an event [i.e., Octavian's alleged slaughter of senators and equestrians after the siege of Perusia] in the account here of the slaughtered sacrificial animals."

731 "We might think of the Somni portae at the end of 6."

It is rhetorically risky for $\mathrm{F}$. to pose many of his suggestions in interrogative form, which often invites responses that range from "I rather think not" to "not a chance!" 
On several occasions F. tells us that a notion is probably not relevant vel sim. The notion is usually one that would not have occurred to anyone else. 142 "There is perhaps no hint of the image of rivers flowing with blood that presages the war in Latium."

146 "There would seem to be no hint in Virgil of a particular link between Turnus' father and Diomedes ..., though the reader would perhaps draw his own associations."

152 lustrabat "likely no hint here of purification"

155 accipio "no omen here (at least not technically)"

203 "no need to connect any of this with Quirinus or Romulus"

251 "There is no need to assume that its absence [sc. of est] reflects something of the heightened state of anxiety as the giant seeks some means of light, though that sentiment may lurk."

270 custos "probably with no allusion to the temple of Hercules Magnus Custos in the Circus Flaminius"

319 "no hint in Virgil that Cronus/Saturn was a byword for that which was outdated and hopelessly old-fashioned"

372 "no hint in Virgil of the hate Homer ascribes to Hera regarding Zeus"

385 "probably no reference to Cicero's coetus populi"

462 on Evander's two dogs "no hint of any Cerberan associations"

528 "It is perhaps overly subtle to see an allusion to the Epicurean argument that clouds were responsible for thunder."

640 armati "there need not be any hint of the threat of future combat, but the idea is not excluded."

711 magno ... corpore "there is no indication that the river is violently shaking in its grief at Cleopatra's defeat."

The note on 670 contains a rare example of an idea that seems both new and plausible: the suggestion (which F. never quite makes explicit) that Virgil was inspired to place Catiline and Cato in the Underworld by the passage of Sallust's Bellum Catilinae (52.13) in which Cato twits Caesar for lack of belief in the Underworld and its punishments.

When faced with an interpretative choice, F. often appears to want to have things both ways.

90 rumore/Rumone. F. seems at first to side with those who reject Rumone, while feebly suggesting that "it is possible that the name of the god was softly heard even with the reading rumore." But later in the note he writes "one is left to wonder whether the Medicean preserves the original reading here."

630 fetam "both senses may be present here (especially the latter)"

631 lambere matrem "There may be a deliberate ambiguity, given that both 'pups' and mother are licking each other" (but that, of course, begs the question). In the next note F. seems to choose: "the (surrogate) mother is licked."

668-9 on Catiline's punishment "Virgil may be deliberately playing on several images simultaneously."

670 on Cato "once again, Virgil brilliantly plays with ambiguous references" (Cato is both Censor and Uticensis). But the following note 
on Catonem brooks no ambiguity, taking the reference to be to the later Cato.

Horror vacui is an occupational disease of commentators. F. has an acute case; he often fills space with notes that state the obvious.

62 cernis "once again with emphasis on the visual aspect. The river can be seen at any time; the god's presence is manifestly apparent"

72 sancto "the river is made vividly sacred and holy by the manifestation of its titular, tutelary god"

75 pulcherrimus "the emphasis of the adjective is on physical appearance"

87 tacita ... unda "the emphasis is on the quiet and silence of the calmed river in the still of the night"

109 cuncti "Virgil's point is to underscore how everyone fled the sight of the Trojan fleet in terror"

117 vides "the poet again highlights the visual image"

148 "the adverb <penitus> coordinates closely with omnem with respect to the sense of totality the two words share"

157 memini "continuing the strong emphasis on memory and recollection"

161 ipsum "the intensive and the repeated patronymic serve to make the point abundantly clear: the son of Laomedon is solemnly remembered."

188 Troiane "a key reminder on the cusp of the Cacus story that the principal audience member for Evander's story is a Trojan"

190 aspice "deictic, and with visual power"

201 auxilium adventumque dei "Evander declares what a past age brought to Latium: the help and advent of the god"

223 "certainly either reading [sc. oculis or oculi] continues the emphasis on the visual"

228 ecce "with deictic force"

233 saxis "the stony emphasis continues"

234 altissima visu "the emphasis on the visual continues"

252 ingentem fumum "the smoke is huge because the monster is so massive"

253 domum "this is Cacus' abode"

255 ignem "Cacus was fire-breathing"

258 ingentem "further accumulation of emphatic details about immense size"

271 maxima "a clear indication of the celebrated Ara Maxima"

353 vidisse "again with an emphasis on the visual"

355 haec "continuing the deictic demonstratives"

363 haec "yet another deictic demonstrative"

399 decem ... annos "the numerical specificity refers to the tradition of the length of the war"

464 memor "once again the power of memory"

477 ostentat "the visual element once again"

510 exhortarer "the verb describes an act of strong encouragement"

516 cernere "the visual element" 
553 aureis "the passage closes on a chromatic note"

588 conspectus "the visual element"

604 videri "another visual tableau"

618 oculos "the emphasis is again on the visual"

631 huic "with deictic force"

689 totum "emphasizing the size and scope of the battle"

697 respicit "the backward glance"

716 totam ... per urbem "the adjective expresses the immense spread of the sacred edifices throughout Rome"

729 Volcani "a final mention of the god who was responsible for the crafting of the shield"

F. is fond of coining outré adjectives from Greek or Roman proper names. Some examples: p. 94 Nepotian (i.e., found in Nepos), p. 126 Atacine Varro (also p. 602) and Varran, p. 191, 330 Plautan (also pp. 684, 740), p. 218 Plautian, p. 239 Mercurian, pp. 262 ff. Atlantean, p. 278 Didonian (also p. 554), p. 280 Junonian (et alibi, e.g. p. 715), p. 314 Lucanian (also pp. 507, 527), p. 321 Venusian (cf. pp. 581, 620 "the Venusian portent," p. 583 "the Venusian arma" (sim. p. 647), p. 588 "the Venusian promises"), p. 623 "the Luciferian/Venusian note"),

p. 370 Vulcanian (cf. p. 376 "the Vulcanian reliance on the Cyclopes," p. 388 "the Cyclopean response to the Vulcanian orders," p. 504 "the Vulcanian labor," also pp. 509, 539, 588, 745), p. 403 “a Pholoean stopover," p. 444 "the Carmentian prophecy," p. 469 "the Palatinian Romulean hut," p. 484 "the Auroran request for divine arms," p. 623 Luciferian, p. 649 Quintan (i.e., relating to Quintus of Smyrna, also p. 721), p. 668 "the Clusian" (i.e., Lars Porsena), p. 669 "the Aeneadic defense of liberty," p. 684 Afranian, p. 702 "the Varronic victory," p.

707 "Neptunian associations," p. 747 "the Anchisean admonition."

Somewhat analogous is F.'s regular use of "Danielis," hardly transparent as a way of referring to Servius Auctus.

F. shows a similar tendency in the use of common nouns and adjectives: p. 322 "<Cacus> carried himself about in igneous swagger," p. 330 "any solemn religious rite of abiogenetic efficacy," p. 348 "Herculean bruxism," p. 360 "argentine epic" (cf. p. 432 "an argentine age ... a brazen <age>," p. 680 "the argentine representation of the light complexion of the northern invaders," p. 691 "argentine dolphins"), p. 398 "a story of infantile strangulation of herpetological horrors" (cf. p. 715 "Cleopatra does not yet see her herpetological fate").

Fittingly for the author of an article entitled "A poetic menagerie," F.'s mannered references to animals would fill a small zoo: p. 301 "warring taurines" (cf. p. 325 "his taurine spoils"), p. 329 "bovines" for "cattle," p. 654

${ }^{8}$ For his part S. in the Introduction has "Hermetian cattle theft" (p. 16), "the Didonic trap" (p. 22), and "the lupine Etruscan Arruns" (p. 22 n. 88), unless these are contributions by F. 
"the lupine nurse of the future Rome" ("lupine" also p. 447, twice on p. 656, twice again on p. 665, twice on pp. 682-3), p. 664 "a porcine sacrifice" (cf. p. 736 "porcine offering"), p. 665 "the poet's porcines."

One would like to think that such language is employed in a spirit of whimsy, but one is not sure.

F. also displays a weakness for Germanisms, perhaps thinking them more impressive than their English equivalents; so we have Anachronismus, Bienenstaat, Waffenübergabe, Aeneas' Schild, even Allecto-Szene.

Selected errata (not including simple typos):

P. 72 open quotation mark missing before 499 o Maeoniae delecta iuuentus

P. 74 close quotation mark missing at end of 519

P. 89 "the Neptunian fields redden[s] with fresh bloodshed"

P. 89 "the Nile, with i<t>s vast body"

P. 106 on 8 in the quotation from Ovid Met. 7.653 priscus should be priscis

P. 113 "the notorious trickery of the Trojans" should be "of the Greeks" (as at the beginning of the paragraph). This could almost qualify as a Freudian slip, given F.'s eagerness to impute trickery to Aeneas.

P. 122 "the influence on Aeneas' anxious thoughts are less clearly expressed"] is

P. 125 "The image thus closes on a powerful, almost surprise note of place and locale"] surprising?

P. 136 (and passim, including bibliography) Putnam's Poetry of the Aeneid (1965) is dated to 1966.

P. 140 on $37 q u i$ "For the emphasis on the relative by its lack of postponement, see Eden ad loc." Qui is here postponed to follow Troianam ex hostibus urbem. Eden's discussion notes that it is less common for the relative to be postponed beyond the second position in the clause, as here.

P. 171 on 61 "Virgil uses only the nominative honos." Since the lemma is honorem, this sentence cannot mean what it seems to. F. meant to say that Virgil uses only the nominative form honos, never honor.

P. 179 on 68 "The emphasis ... contrast $<\mathrm{s}>$ with the river god's injunction"

P.193 on 80. Something amiss with the reference to Zwierlein 2000 pp. 45-6? The only relevant reference I can find is on p. 164, where 3.471 is listed among repeated verses that Zwierlein ascribes to Montanus. (Also Zwierlein's book is dated 1999.)

P. 196 on 82 Daniel<i>s

P. 201 on 86 F. contradicts himself within three lines, first saying that longa does not necessarily refer to the perception that the night was long, and later that "we have the detail that the night ... was 'long'." P. 215 on 96 F. gives no author's name for a Glotta 1972 article on elision, perhaps because none appears in the issue's table of contents; the article is the work of the Arbeitsgruppe für lateinische Metrik und Stilistik, Tübingen. 
P. 251 on 127. The citation from Lucretius omits 477, which contains the word (Graiugenarum) that Virgil is said to have borrowed.

P. 252 on 128 The reference to Horace C. 3.14.8 is missing the book number.

P. 267 on $140 \mathrm{P}$ reads creditis instead of credimus, not instead of auditis.

P. 291 The corrector of $\mathrm{P}$ altered intertexto to intertextum, not the other way around.

P. 294 on 171 Reference to Caesar BC missing; it is to 3.35.2.

P. 301 Gastma $<h>$ lszenen

P. 346 There are 21 hypermetric lines in Virgil, not 22. (And is "synapheia" $[$ sic $]$ the correct term for the phenomenon?)

P. 355 "the capital manuscript $<\mathrm{s}>$ are divided"

P. 363 "Gransden ... considers Hercules to be an intermediary figure between Aeneas Troianus and Aeneas Italicus. It can be asked whether Virgil ever presents Aeneas with the latter ethnic designation." What Gransden wrote was that "Hercules here mediates between Aen. the defeated Trojan and Aen. the soon-to-be-victorious Italian."

P.364 on advocat "We may wonder to whom Hercules is making his appeal; there has been no mention of any companion or assistant." If F. had consulted S.'s translation, he would not have wondered: S. renders "Alcides calls upon all his weapons," taking advocat in the sense "summon up" (OLD \#6), a broadening of the verb's sense for which this passage may be the earliest attestation (soon imitated by Ovid Met. 7.138 of Medea, secretas ... advocat artes).

P. 367 on 254 The quotation attributed to Fordyce is actually from Jocelyn.

P. 375 Something amiss here? "Lucan refers to the dead and dying of Curio as a cadaver composition at BC 4.787."

P. 404 on 294 F. misquotes Fordyce, who said that the reference to the killing of Pholus (not to that of the Cretan bull) "awkwardly emphasizes what was not a very creditable exploit."

P. 420 on 313 tanta molis $>$ tanta moles

P. 425 Unfortunate phrasing: "the Medicean originally had rapto here, with a violent note about the life of these early men."

P. 442 on 338 The Petronius reference should be Sat. 72.10, not 72.7.

P. 444 on 340 "the status of Carmentis as a vatis"

P. 444 On quae prima the unattributed quotation is from Fordyce.

P. 447 on 343 "Verses 343 and 344 end with words with reference wolves"] either "which reference" or "with reference to"

P. 458 on 354 "a shield would not easily be wielded in one hand"] the point is rather whether a shield would be wielded in the right hand (dextra)

P. 463 "something of a decline in mortals may be reflected"; morals?

P. 478 "Garrod proposed emending the text of 378 to read incassum vetitos (and not vetitum) volui etc." Garrod proposed replacing -ve tuos with vetitos; F. may be correcting Geymonat, who ascribed the emendation vetitum to Garrod, but his phrasing is easily misunderstood. 
P. 484 on 384 unattributed quotation ("Altogether he cut a splendid figure with his divinely made panoply")

P. 491 (quoting Putnam (1965), pp. 138-9) "metaphorically the very fire which helps forge $[\mathrm{t}]$ the shield"; presumably an autocorrection?

P. 495 on 397 I can find no evidence that Tiberius Claudius Donatus read tunc. (S., following Geymonat, ascribes it to Iulius Rufinianus.)

P. 502 on 408 "Commentators have associated the image of Vulcan's rising at the time when the work of weaving is commenced have compared Homer" etc.

P. 505 on 412 Lanam fecit oddly appears as though it were a lemma.

P. 538 "The sword will, in fact, prove to be as pointless as those [?] of

Priam 2.509-11"

P. 574 duri salacia casus $>$ solacia

P. 586 "Williams see<s> the use of the near tautology"

P. 586 "The Trojan hero's reflections in the first movements of Book

11." The first moments?

P. 588 The unattributed quotation is from Eden.

P. 608 "three times that he had to be lain low in death"

P. 616 on 581 F. gets Eden's point backward; he thought that the order sera et sola (P etc.) offered "a slight gain in rhetorical point" by having the comparative sera precede the superlative sola.

P. on 596 the quotation from Skutsch omits the word "perhaps."

P. 634 I do not understand the comment that the combination videri poterat was "admitted to verse by Ovid (Met.)."

P. $661 \mathrm{~S}<\mathrm{c}>$ hrader

P. 685 "there may be a sling [?] at Antony"

P. 686 "any muted element of such praise would be a discrete reflection"] discreet

P. 698 "the phrase directly echo<es> 3.527"

P. 703 F. quotes E. as calling Heinsius' conjecture Phariis "brilliant";

in fact E. called it "ingenious ... based on a misunderstanding."

P. 711 Wigodwky > Wigodsky

P. 743 J. W. Ziolkowski > J. M.

A few miscellaneous observations before I conclude.

In the preface F. thanks Katelyn McGarr for "images," but I can find only one (on p. 92), a photograph of Trajan's Forum and Column (mislabeled "The Forum Romanum").

There are no maps, an unfortunate omission in a book in which topography features so prominently. Gransden has a map of the site of Rome. O'Hara has two, one of Evander's Rome and another of places mentioned in the description of the shield.

The rubric "Index rerum" has been applied literally, with no entries for persons. So no listings for Homer, Apollonius Rhodius, Callimachus, Ennius, Catullus, or Servius, among many others.

The criteria for inclusion in the bibliography are unclear. Some 30 items cited in the introduction do not appear in the bibliography, including one article described as "classic" and another called "exemplary." Many items 
cited in the commentary are also not found in the bibliography (e.g., much of the bibliography on the Hercules and Cacus episode).

The notion of a definitive commentary on a classical text is as chimerical as the idea of a definitive edition, arguably even more so, since the possibilities for additional comment

increase much more rapidly than the evidence on which a text may be based. That is especially true of a work as complex as the Aeneid. So it is no criticism to say of F.'s commentary that it does not supersede any of its predecessors. It is, however, not unreasonable to expect that a large-scale commentary will incorporate much of what is most valuable in earlier work, and in that respect F.'s commentary accomplishes considerably less than might have been hoped for.

Writing this article gave me the opportunity to renew my acquaintance with the commentary Triumvirate of the 1970s and to better appreciate their distinctive qualities. The gain was greatest with Eden's commentary, which I had long regarded as rather bloodless (probably because of his disdain for "entirely subjective reactions to Virgil's poetry" (p. ix)), but which on this reading seemed acutely sensitive to Virgil's language and meter. But the greatest pleasure lay in getting to know James O'Hara's commentary in the Focus series, which, although modestly billed as "adapted from the commentaries of T. E. Page," actually offers a fully updated and rethought approach to the book. O'Hara's bibliographical references are superior to F.'s for being more focused and discriminating, and he excels in culling useful observations from previous commentaries. A reviewer has written that "for accessibility, affordability, and portability, O'Hara's commentary is hard to beat." I would add that it also offers the highest proportion of useful comment per page of any commentary on Aeneid 8.

${ }^{9}$ M. Loar, BMCR 2018.09.42. 